\title{
Clinical-epidemiological study of caseous lymphadenitis in goats in the state of Pernambuco
}

\author{
Estudo clínico-epidemiológico da linfadenite caseosa em caprinos no estado de Pernambuco
}

\section{Tamyres Izarelly Barbosa da Silva ${ }^{1 *}$, Artur Cezar de Carvalho Fernandes ${ }^{2}$, Luiz Carlos Fontes} Baptista Filho ${ }^{3}$, Daniel Dias da Silva ${ }^{4}$, Renata Gomes Revorêdo ${ }^{4}$, Lúcio Esmeraldo Honório de Melo ${ }^{4}$

${ }^{1}$ Universidade Federal do Acre, Rio Branco, AC, Brasil. *Author for correspondence: tamyres_ibs@hotmail.com

${ }^{2}$ Universidade Federal da Paraíba, João Pessoa, PB, Brasil.

${ }^{3}$ Universidade Federal do Agreste de Pernambuco, Garanhuns, PE, Brasil.

${ }^{4}$ Universidade Federal Rural de Pernambuco, Recife, PE, Brasil.

\begin{abstract}
Caseous lymphadenitis (CL), a contagious infectious disease caused by Corynebacterium pseudotuberculosis, stands out with great economic relevance for goat breeding in the country because it is one of the main causes of carcass condemnation and intense depreciation of the leather of small ruminants. The objective was to carry out a descriptive study of the clinical and epidemiological aspects of $\mathrm{CL}$ in goats in the state of Pernambuco and also to evaluate the detection of $C$. pseudotuberculosis in milk, blood, and stool samples by real-time PCR. Six hundred and forty-three goats were evaluated, of which 76 (11.8\%) presented clinical signs suggestive of CL. And $88.9 \%$ (24/27) of the breeding was considered focus. Among symptomatic animals, 25 were selected and submitted to the collection of abscess content for bacteriological isolation. Milk, blood, and stool samples were analyzed for PLD gene detection by realtime polymerase chain reaction (PCR). Out of the 25 samples of abscess content, $72 \%(18 / 25)$ were positive. The PLD gene was detected in the frequencies of $8 \%(2 / 25)$ and $4 \%(1 / 25)$ in milk and blood samples, respectively. Caseous lymphadenitis is possibly widespread in the dairy herds of goats in the state of Pernambuco, especially in adult animals, with a higher occurrence of submandibular lymph node abscesses. The preliminary detection of $C$. pseudotuberculosis by mammary and hematogenous pathways may contribute to future approaches on the mechanisms of organic dissemination performed by the pathogen. However, it has little relevance to diagnosing the disease.
\end{abstract}

KEYWORDS: goats, Corynebacterium pseudotuberculosis, polymerase chain reaction.

\section{RESUMO}

A linfadenite caseosa (LC), doença infectocontagiosa ocasionada pelo Corynebacterium pseudotuberculosis, se destaca com grande relevância econômica para a caprinocultura no país por ser umas das principais causas de condenação de carcaças e intensa depreciação do couro de pequenos ruminantes. Objetivou-se realizar um estudo descritivo dos aspectos clínico-epidemiológicos da LC em caprinos no estado de Pernambuco e, adicionalmente, avaliar a detecção do $C$. pseudotuberculosis em amostras de leite, sangue e fezes por PCR em tempo real. Foram avaliados 643 caprinos, dos quais 76 $(11,8 \%)$ apresentaram sinais clínicos sugestivos de LC. E $88,9 \%(24 / 27)$ das propriedades foram consideradas foco. Dentre os animais sintomáticos, 25 foram selecionados e submetidos à colheita de conteúdo de abscesso para isolamento bacteriológico. Amostras de leite, sangue e fezes foram analisadas para detecção do gene PLD pela reação em cadeia da polimerase (PCR) em tempo real. Das 25 amostras de conteúdo de abscesso, 72\% (18/25) resultaram positivas. O gene PLD foi detectado nas frequências de $8 \%(2 / 25)$ e $4 \%(1 / 25)$ em amostras de leite e sangue, respectivamente. A linfadenite caseosa possivelmente encontra-se disseminada nos rebanhos leiteiros de caprinos do estado de Pernambuco, sobretudo em animais adultos, com maior ocorrência de abscessos em linfonodos submandibulares. A detecção preliminar do $C$. pseudotuberculosis pelas vias mamária e hematógena pode contribuir para abordagens futuras sobre os mecanismos de disseminação orgânica realizados pelo patógeno, apesar de ser pouco relevante para diagnóstico da doença.

PALAVRAS-CHAVE: caprinos, Corynebacterium pseudotuberculosis, reação em cadeia da polimerase. 


\section{INTRODUCTION}

Goat and sheep breeding, previously focused only on subsistence, has become an activity of great socio-economic importance in Brazil. In the Northeast region, the largest portion of the national herd of small ruminants is observed (FAO 2019), whose production is the most developed among the South American countries (LOPES et al. 2012, LU \& MILLER 2019). The productivity indexes of a herd are directly related to the different breeding systems and sanitary control in the properties (SILVA et al. 2014).

In this context, caseous lymphadenitis $(\mathrm{CL})$ stands out with great economic relevance to goat breeding, and it is one of the main causes of low production, carcass condemnation, and intense depreciation of leather in small ruminants (SANTIAGO et al. 2013). Its introduction in the national herds leads to restrictions of commercialization, manufacture, and export of by-products, among others (BRASIL 2008). This contagious infectious disease, caused by Corynebacterium pseudotuberculosis, is characterized by the formation of abscess lesions in superficial and visceral ganglia or organs (RADOSTITS et al. 2007).

In Brazil, the high-frequency rates (NOZAKI et al. 2000, MOTTA et al. 2010, FARIAS et al. 2019) characterize an enzootic state of CL, especially in the Northeast region (RIET-CORREA 2007, MELO et al. 2010, ANDRADE et al. 2012). Values between 24 and 50\% of prevalence were reported, with an emphasis in the state of Pernambuco (RIET-CORREA 2007, ABREU et al. 2008).

However, even considering this scenario of high dissemination in northeastern herds, the literature is scarce regarding clinical data and epidemiological surveys of the disease. Also, bacteriological isolation, the gold standard diagnostic technique, is limited to the identification of symptomatic animals only and serological assays have low sensitivity, bringing several gaps for investigation of inapparent carriers of the bacterium (SEYFFERT et al. 2010, SOARES et al. 2012, BARRAL et al. 2019, ODHAH et al. 2019).

Thus, we aimed to perform a descriptive analysis of the clinical and epidemiological aspects of $\mathrm{Cl}$ in goats in the state of Pernambuco and also to evaluate the detection of $C$. pseudotuberculosis in milk, blood, and stool samples by real-time PCR.

\section{MATERIAL AND METHODS}

The results were presented in the descriptive study method. Sampling was established by nonprobabilistic convenience (THRUSFIELD 2004, MAROTTI et al. 2008), evaluating 643 goats, between males and females, with milk aptitude, aged between five months and eight years, of the Saanen, Toggenburg, and Parda Alpina breeds and of 27 herds from 17 cities of the mesoregions: Metropolitan of Recife, Zona da Mata, Agreste, São Francisco, and Sertão of the state of Pernambuco (Figure 1).

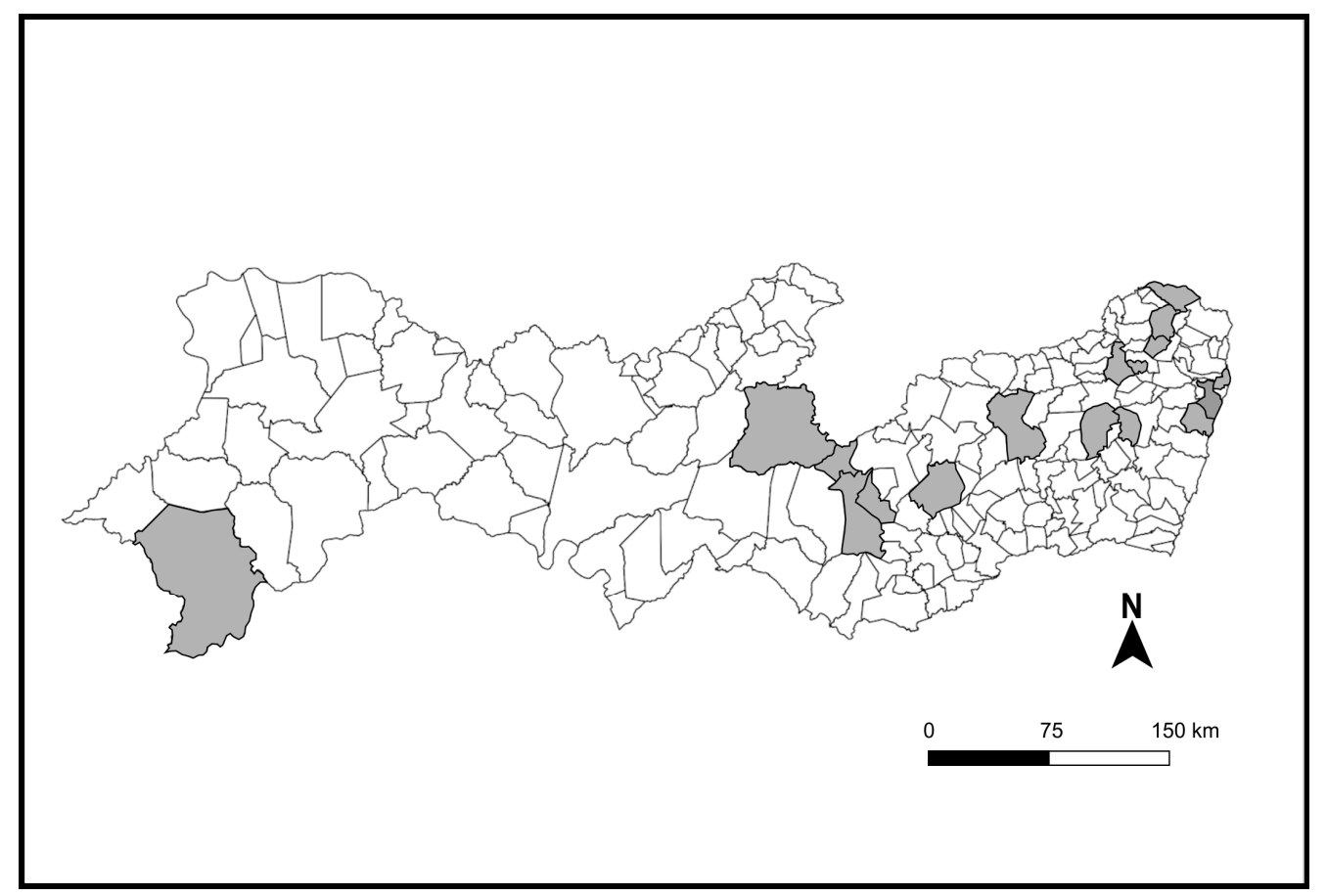

Figure 1. Geographic distribution of the state of Pernambuco, with emphasis (gray) for the 17 municipalities selected for the study.

The animals were submitted to clinical examination, with an emphasis on inspection and palpation of the superficial lymph nodes and the presence of scars suggestive of CL (RADOSTITS et al. 2007). 
Out of these, 25 symptomatic goats were selected for the collection of abscess content by fine-needle aspiration puncture, blood with anticoagulant (ethylenediaminetetraacetic acid - EDTA) by venipuncture of the external jugular, milk, and stool (Figure 2).

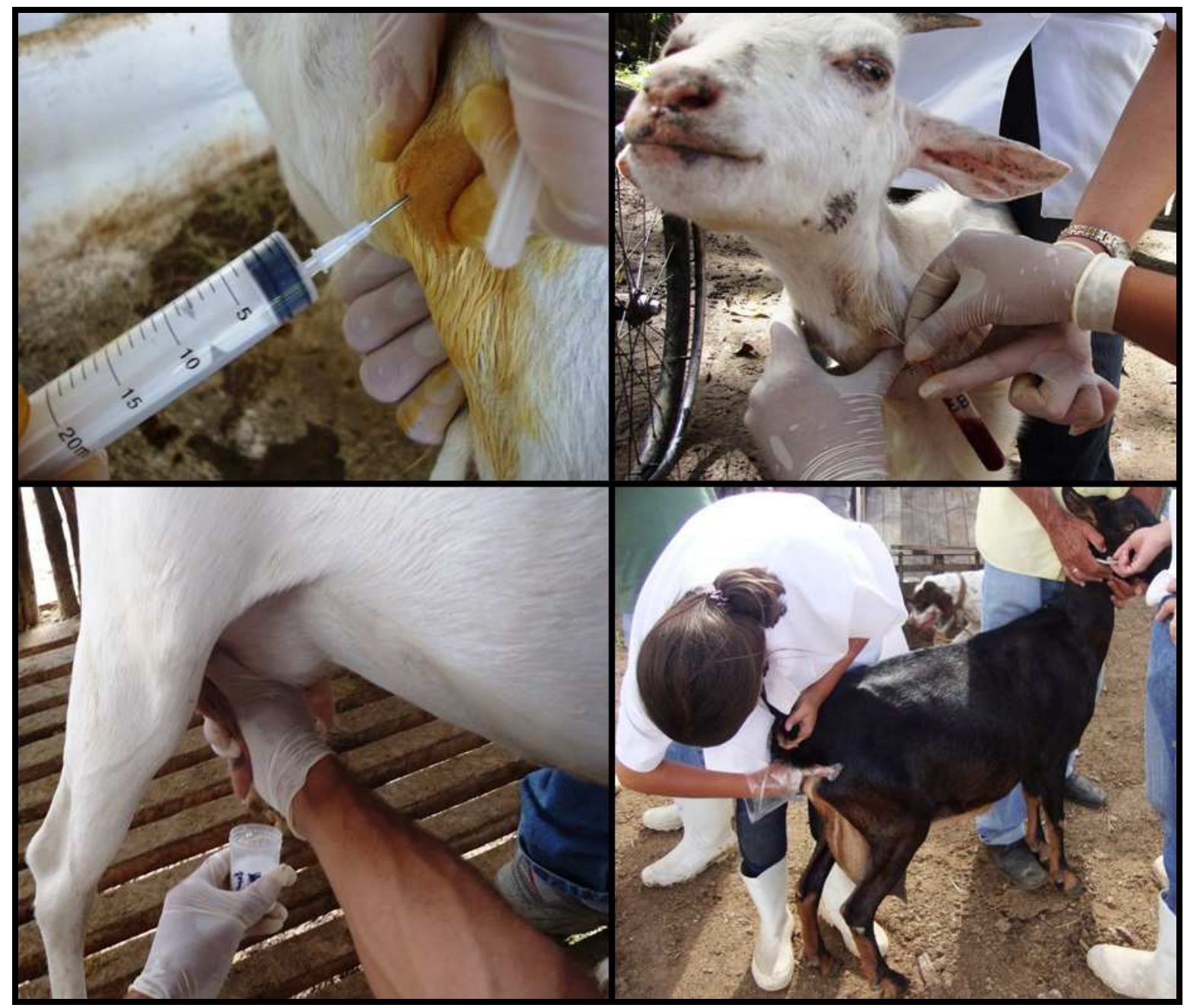

Figure 2. Collection of abscess content, blood, milk, and stool of goats in the state of Pernambuco.

For bacteriological isolation, the abscess content samples were seeded in $5 \%$ sheep blood agar and incubated at $37{ }^{\circ} \mathrm{C}$ for 48 hours. The isolates were characterized by phenotypic and biochemical aspects (MEGID et al. 2016).

Samples of blood, milk, and stool were subjected to DNA extraction and amplification by real-time polymerase chain reaction (PCR), using Blood \& Tissue kit $\left(\right.$ Qiagen ${ }^{\circledR}$ ) and Master Mix Sybr Green (Qiagen ${ }^{\circledR}$ ) commercial kits, according to the manufacturer's recommendations (ÇENTIKAYA et al. 2002), with adaptations. The sequence of primers, the target gene, and the length of the amplified fragment expected (PACHECO et al. 2007) are described in Table 1. For positive control, samples of purified cultures were used. For the negative control, the DNA was excluded from the reaction.

Table 1. Target gene, the sequence of primers, and length of the amplified fragment for Corynebacterium pseudotuberculosis.

\begin{tabular}{|c|c|c|}
\hline Target gene & Sequence of primers $5^{\prime}$ to $3^{\prime}$ & Fragment size (pb) \\
\hline \multirow{2}{*}{ PLD } & $\mathrm{D}^{\mathrm{a}}$ - GGC GGT GGC GGA GTT GAA GGC GAT G & \multirow{2}{*}{203} \\
\hline & $\mathrm{R}^{\mathrm{b}}$ - GCC GCG AGC GAG TCT GGG CGA TGT C & \\
\hline
\end{tabular}

$\overline{\mathrm{a}}=$ direct $^{\mathrm{b}}=$ reverse.

All data from this study were analyzed using descriptive statistics, using relative and absolute distribution. The results of the diagnostic tests were compared to calculate sensitivity and specificity, considering the bacteriological culture as the gold test (THRUSFIELD 2004). 


\section{RESULTS}

Out of the 643 goats examined, $76(11.8 \%)$ presented clinical signs suggestive of $C L$ due to the appearance of abscess lesions $(71 / 76-93.4 \%)$ or scars $(5 / 76-6.6 \%)$, especially in areas corresponding to the superficial lymph nodes (Figure 3). And $88.9 \%$ (24/27) of the breeding was considered focus, that is, they had at least one symptomatic animal. The most frequent age group varied between one and three years of age (50/76 - 65.8\%). However, younger animals were also observed as having abscesses.

Among the sites with the greatest involvement by the abscesses, the superficial lymph nodes presented $72.4 \%(55 / 76)$ of frequency, with emphasis on the submandibular (Table 2). During the aspiration puncture of the abscess lesions, drainage of yellowish contents with a foul smell and purulent appearance was observed.

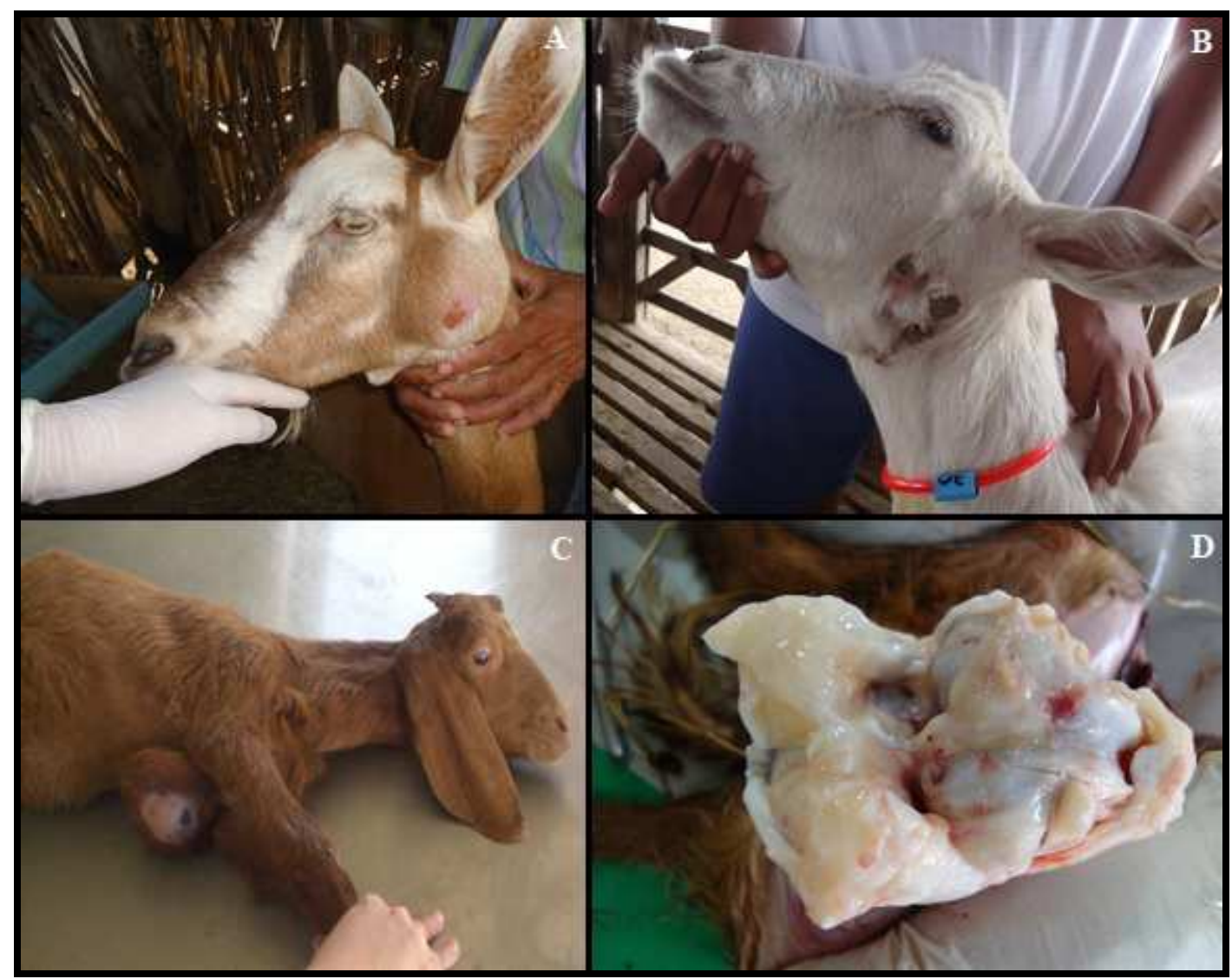

Figure 3. Goats evaluated in the state of Pernambuco. A) Abscess in the parotid region; B) Submandibular lymph node scar; C) Abscess in the xiphoid region; D) Fibrinolytic joint injury.

Table 2. Body distribution of abscess lesions in goats in the state of Pernambuco.

\begin{tabular}{lc}
\hline \multicolumn{1}{c}{ Location } & Frequency \\
\hline Articulation & $1.3 \%(1 / 76)$ \\
Side region & $10.5 \%(8 / 76)$ \\
Parotid lymph node & $3.9 \%(3 / 76)$ \\
Popliteal lymph node & $3.9 \%(3 / 76)$ \\
Precrural lymph node & $9.2 \%(7 / 76)$ \\
Pre-scapular lymph node & $19.7 \%(15 / 76)$ \\
Submandibular lymph node & $35.5 \%(27 / 76)$ \\
Mammary gland & $9.2 \%(7 / 76)$ \\
\hline
\end{tabular}

From this symptomatic population, a portion was selected for microbiological and molecular study. Out of the 25 samples submitted to bacteriological isolation, 18 (72\%) resulted in whitish colonies, approximately two millimeters in size, composed of the Gram-positive bacteria, catalase and urease positive, glucose fermenters, and non-gas producing bacteria, characteristics of $C$. pseudotuberculosis.

The PLD gene was detected at the frequencies of $8 \%(2 / 25)$ and $4 \%(1 / 25)$ in milk and blood samples, respectively, by real-time PCR (Figure 4, Table 3), whose sensitivity presented for such samples was $11.1 \%$ and $5.8 \%$. 


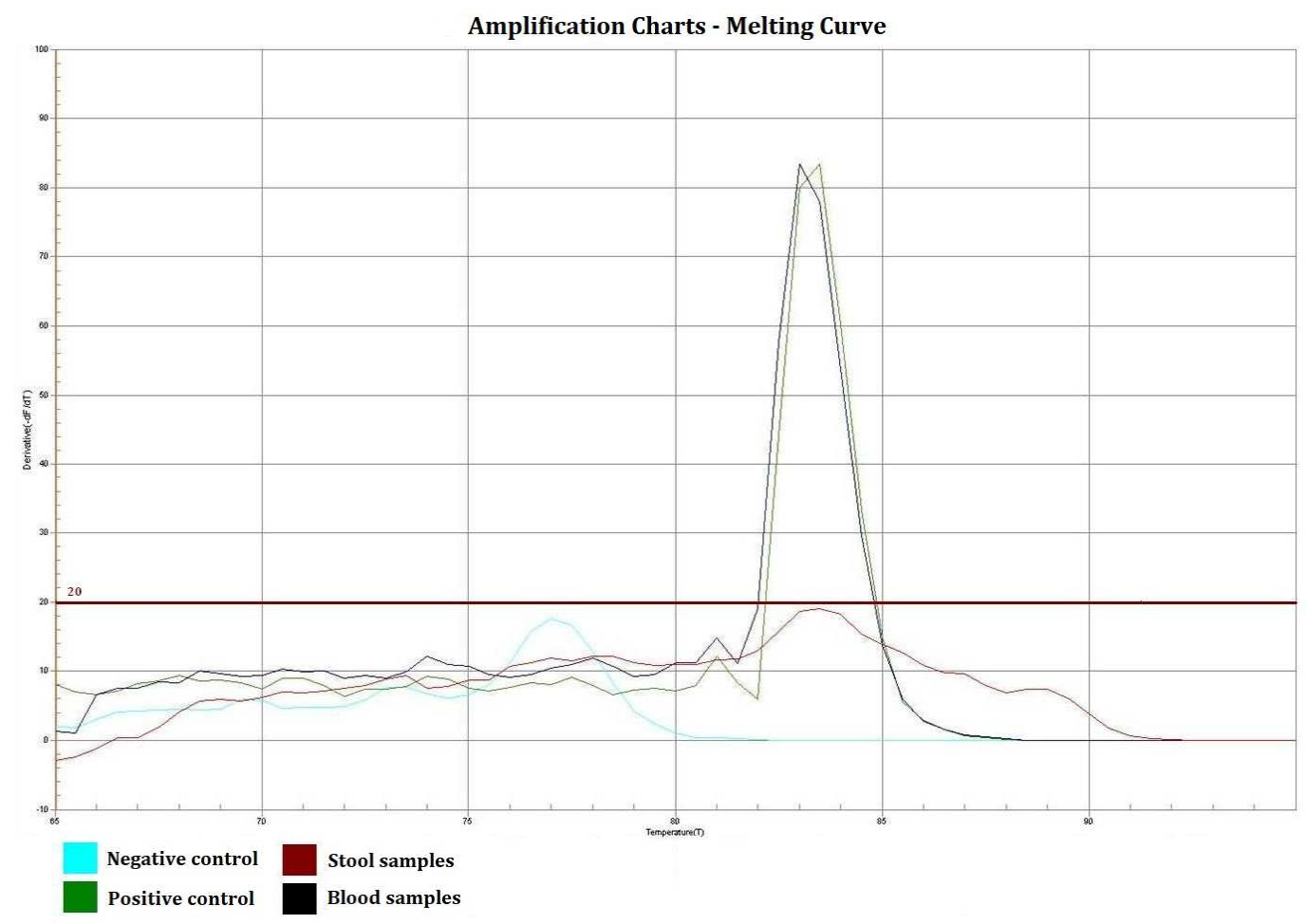

Figure 4. Real-time PCR graph for the PLD gene (C. pseudotuberculosis), demonstrating amplification of the positive control and the clinical sample of goats in the state of Pernambuco.

Table 3. Frequency of bacteriological isolation and real-time PCR in the identification of $C$. pseudotuberculosis in different goat samples from the state of Pernambuco.

\begin{tabular}{|c|c|c|c|c|}
\hline \multirow{2}{*}{ SAMPLES } & \multirow{2}{*}{$\frac{\text { Bacteriological isolation }}{\text { Abscess }}$} & \multicolumn{3}{|c|}{ Real-time PCR } \\
\hline & & Milk & Blood & Feces \\
\hline 1 & + & - & - & - \\
\hline 2 & - & - & - & - \\
\hline 3 & - & - & - & - \\
\hline 4 & + & - & - & - \\
\hline 5 & - & - & - & - \\
\hline 6 & - & - & - & - \\
\hline 7 & + & - & - & - \\
\hline 8 & + & + & - & - \\
\hline 9 & + & - & - & - \\
\hline 10 & + & - & - & - \\
\hline 11 & - & - & - & - \\
\hline 12 & + & - & - & - \\
\hline 13 & - & - & - & - \\
\hline 14 & + & + & - & - \\
\hline 15 & + & - & - & - \\
\hline 16 & + & - & - & - \\
\hline 17 & + & - & - & - \\
\hline 18 & + & - & - & - \\
\hline 19 & + & - & - & - \\
\hline 20 & + & - & + & - \\
\hline 21 & + & - & - & - \\
\hline 22 & + & - & - & - \\
\hline 23 & + & - & - & - \\
\hline 24 & - & - & - & - \\
\hline 25 & + & - & - & - \\
\hline Total & $18(72 \%)$ & $2(8 \%)$ & $1(4 \%)$ & $0(0 \%)$ \\
\hline
\end{tabular}

\section{DISCUSSION}

The frequency of suspected goats for $\mathrm{CL}$ in the population studied $(11.8 \%-76 / 643)$, based on clinical findings, was slightly higher than that registered in the semi-arid region of Paraíba $(7.7 \%-49 / 640)$ 
(ANDRADE et al. 2012). However, it is still lower than the rates for the northeastern region of the country, ranging from 24 to $50 \%$ (RIET-CORREA 2007, ABREU et al. 2008).

The use of surgical puncture or excision of abscesses, which has become a common practice in breeding to improve the external appearance of goats for commercialization or slaughter, has probably limited the identification of more clinical cases (WINDSOR 2011). ANDRADE et al. (2012), for example, reported that $59 \%(29 / 49)$ of the animals evaluated in the state of Paraiba presented only scars.

The efficacy of this lesion-restricted procedure, often merely aesthetic, is questionable because it treats the $C L$ as a disease with a systemic spread in the body. This situation represents a high risk to the health of the herds, due to the consequent maintenance of infected animals and potential disseminators of the disease (NOZAKI et al. 2000, FARIAS et al. 2019).

The high frequency of properties considered as focus $(88.9 \%-24 / 27)$ demonstrates the magnitude of the spread of $C$. pseudotuberculosis in the herds of the state of Pernambuco and the need to implement strategic measures to control CL (MOTTA et al. 2010).

The age group seems to be an important aspect in which older animals, especially over two years old, are more affected. There are few reports on the occurrence of $C L$ in younger goats, as observed in this study. Beyond direct contact with diseased animals, there is a possibility of infection by vertical transmission, especially in situations of high herd prevalence and inadequate management practices (MEGID et al. 2016, FARIAS et al. 2019).

The location of abscesses in superficial lymph nodes, mainly the submandibular ones, similar to the lesions reported in sheep in the Middle East (DUNO et al. 2015), may be associated with the access of $C$. pseudotuberculosis through the oral cavity by contaminated food (ASHFAQ \& CAMPBELL 1979). On the other hand, the involvement of the pre-scapular lymph nodes is related to the abrasions caused by fence wires or xerophytic vegetation, promoting a gateway to the agent (SOUZA et al. 2011, ANDRADE et al. 2012).

The articular picture of the young goat identified in this study is a rare finding and corroborates the hypothesis of hematogenous dissemination of the bacterium (VALLI \& PARRY 1993).

Regarding the bacteriological culture of the abscess content, the frequency of isolation $(72 \%-18 / 25)$ was equivalent to that described by ANDRADE et al. (2012), which detected $68.2 \%$ (15/22) of positivity in samples of goats and sheep with abscesses.

In turn, real-time PCR is a technique considered the gold standard for the diagnosis of $C L$ in the French Center for Reference in Corynebacterioses of the Pasteur Institute, from samples previously cultured (BARRAL et al. 2019). ÇETINKAYA et al. (2002) demonstrated high sensitivity and specificity with the use of PCR applied to strains isolated from the abscess. However, its use in blood, milk, and stool samples had not yet been performed, only in certain tissues collected at necropsy (LATIF et al. 2015, POINTON et al. 2019, ODHAH et al. 2019).

The presence of $C$. pseudotuberculosis in milk elucidates the spread of the bacterium during milking or by hematolymphatic route to the supra-mammary lymph nodes and the parenchyma of the mammary gland (BAIRD \& FONTAINE 2007), promoting the formation of abscesses and leading to economic losses for dairy producers and by-products industries (NABIH et al. 2018). In addition, the destination of milk from these properties demonstrates the importance not only of transmission to the offspring but also of public health, since it represents a zoonosis for individuals consuming goat's milk in natura, a product traditionally marketed in the northeastern backlands (ABREU et al. 2008, BASTOS et al. 2011).

The identification of the $C$. pseudotuberculosis in the blood has been related to the dissemination of the agent via the hematogenous route (BAIRD \& FONTAINE 2007), ratifying the relevance of sanitary control for the reuse of needles in different animals and the lack of disinfection in surgical procedures (FARIAS et al. 2019).

Although bacteria are carried by macrophages and need to circulate through the hematogenous or lymphatic pathway to reach other sites, a reduced frequency in the blood was observed, probably due to the low-grade transient bacteremia assumed by the C. pseudotuberculosis (VALLI \& PARRY 1993).

As for the digestive route, there is a record of the isolation of this pathogen in stomach contents, mesenteric lymph nodes (RADOSTITS et al. 2007), and stool (BENHAM et al. 1962), referring to oral infection as the gateway (DORELLA et al. 2006). It is also known that fecal material is an important source of $\mathrm{CL}$ transmission, given the high survival capacity of $C$. pseudotuberculosis in this medium (BAIRD \& FONTAINE 2007, WINDSOR 2011).

However, VALLI \& PARRY (1993) later described that the intestinal tract presented no risk for bacterial fixation. RIBEIRO et al. (2001) were also not successful in bacterial isolation in the stool of naturally 
infected goats, similar to those observed in this study. Thus, more detailed studies on the possibility of eliminating C. pseudotuberculosis in fecal samples are indicated.

Comparing the microbiological and molecular results, it is observed low sensitivity in the identification of C. pseudotuberculosis in specimens different from the abscess content. The purpose of detecting the bacteria in different biological samples would be to contribute to the early identification of the infection in inapparent carriers, as well as to understand its pathways of organic dissemination better. However, this study showed that efforts to analyze milk, blood, and stool in goats with caseous lymphadenitis have little relevance for the diagnosis. Nonetheless, we demonstrated that they are possible routes of transmission, serving as a warning to public health entities.

\section{CONCLUSION}

Caseous lymphadenitis is possibly widespread in the dairy herds of goats in the state of Pernambuco, especially in adult animals, with a higher occurrence of submandibular lymph node abscesses. The preliminary detection of $C$. pseudotuberculosis by mammary and hematogenous pathways may contribute to future approaches on the mechanisms of organic dissemination performed by the pathogen. However, it is of little relevance to diagnosing the disease.

\section{ACKNOWLEDGEMENTS}

To the technical staff of the Laboratories of Bacterioses and Viruses of Domestic Animals of the Veterinary Medicine Department of the Rural Federal University of Pernambuco.

\section{REFERENCES}

ABREU SRO et al. 2008. Comparação genotípica de isolados de Corynebacterium pseudotuberculosis de caprinos e ovinos do sertão de Pernambuco. Pesquisa Veterinária Brasileira 28: 481-487.

ANDRADE JSL et al. 2012. Ocorrência e fatores de risco associados à infecção por Corynebacterium pseudotuberculosis em caprinos e ovinos do semiárido paraibano. Pesquisa Veterinária Brasileira 32: 116-120.

ASHFAQ MK \& CAMPBELL SG. 1979. A survey of caseous lymphadenitis and its etiology in goats in the United States. Veterinary Medicine, Small Animal Clinician 74: 1161-1165.

BAIRD GJ \& FONTAINE MC. 2007. Corynebacterium pseudotuberculosis and its role in ovine caseous lymphadenitis. Journal of Comparative Pathology 137: 179-210.

BARRAL TD et al. 2019. A panel of recombinant proteins for the serodiagnosis of caseous lymphadenitis in goats and sheep. Microbial Biotechnology 12: 1313-1323.

BASTOS BL et al. 2011. Corynebacterium pseudotuberculosis: Immunological responses in animal models and zoonotic potential. Journal of Clinical and Cellular Immunology 4: 5 .

BENHAM CL et al. 1962. Corynebacterium pseudotuberculosis and its role in diseases of animals. Bureau of Animal Health 32: 645-657.

BRASIL. 2008. Ministério do Desenvolvimento, Indústria e Comércio Exterior. Agência Brasileira de Desenvolvimento Industrial. Relatório Setorial: indústria do couro, calçados e artefatos. Brasília: ABDI. 44p.

ÇETINKAYA B et al. 2002. Identification of Corynebacterium pseudotuberculosis isolates from sheep and goats by PCR. Veterinary Microbiology 88: 75-83.

DORELLA FA et al. 2006. Corynebacterium pseudotuberculosis: microbiology, biochemical properties, pathogenesis and molecular studies of virulence. Veterinary Research 37: 201-218.

DUNO AD et al. 2015. Caracterización epidemiológica de la linfadenitis caseosa en rebaños caprinos de la península de Paraguaná, Venezuela. Revista del Medicina Veterinaria 31: 35-45.

FARIAS AEM et al. 2019. Seroepidemiological characterization and risk factors associated with seroconversion to Corynebacterium pseudotuberculosis in goats from Northeastern Brazil. Tropical Animal Health and Production 51: 745-752.

FAO. 2019. Food and Agriculture Organization of the United Nations statistical databases [internet]. Available in: http://faostat.fao.org/. Accessed in: 10 sep. 2019.

LATIF NA et al. 2015. Isolation and detection of Corynebacterium pseudotuberculosis in the reproductive organs and associated lymph nodes of non-pregnant does experimentally inoculated through intradermal route in chronic form. Veterinary World 8: 924-927.

LOPES FB et al. 2012. Spatialization of climate, physical and socioeconomic factors that affect the dairy goat production in Brazil and their impact on animal breeding decisions. Pesquisa Veterinária Brasileira 32: 1073-1081.

LU CD \& MILLER BA. 2019. Current status, challenges and prospects for dairy goat production in the Americas. AsianAustralasian Journal of Animal Sciences 32: 1244-1255.

MAROTTI J et al. 2008. Amostragem em pesquisa clínica: Tamanho da amostra. Revista de Odontologia 20: 186-194. MEGID J et al. 2016. Doenças infecciosas em animais de produção e de companhia. Rio de Janeiro: Roca. 1296p.

MELO LEH et al. 2010. Monitoramento clínico-epidemiológico relacionado ao diagnóstico diferencial entre tuberculose caprina e linfadenite caseosa. In: Seminário Nacional sobre Brucelose e Tuberculose Animal. Anais... Belo Horizonte: 
UFMG.

MOTTA RG et al. 2010. Infecções por Corynebacterium pseudotuberculosis em animais de produção. Veterinária e Zootecnia 17: 200-213.

NABIH AM et al. 2018. Corynebacterium pseudotuberculosis mastitis in Egyptian dairy goats. Veterinary World 11: 15741580.

NOZAKI CN et al. 2000. Extirpação cirúrgica dos abscessos da linfadenite caseosa em caprinos. Arquivos do Instituto Biológico 67: 187-189.

ODHAH MN et al. 2019. Clinico-pathological responses and PCR detection of Corynebacterium pseudotuberculosis and its immunogenic mycolic acid extract in the vital organs of goats. Microbial Pathogenesis 135: 1-11.

PACHECO LGC et al. 2007. Multiplex PCR assay for identification of Corynebacterium pseudotuberculosis from pure cultures and for rapid detection of this pathogen in clinical samples. Journal of Medical Microbiology 56: 480-486.

POINTON A et al. 2019. Comparison of postmortem inspection procedures for detecting caseous lymphadenitis of Australian sheep and goats. Veterinary Record 185: 54.

RADOSTITS OM et al. 2007. Veterinary Medicine: A textbook of the diseases of cattle, horses, sheep, pigs, and goats. 10.ed. Philadelphia: W.B. Saunders. 2180p.

RIBEIRO MG et al. 2001. Punção aspirativa com agulha fina no diagnóstico do Corynebacterium pseudotuberculosis na linfadenite caseosa caprina. Arquivos do Instituto Biológico 68: 23-28.

RIET-CORREA F. 2007. Linfadenite caseosa. In: RIET-CORREA F et al. Doenças de Ruminantes e Equídeos. 3.ed. Santa Maria: Pallotti. p.347-352.

SANTIAGO LB et al. 2013. In vivo evaluation of antiseptics and disinfectants on control of Caseous Lymphadenitis: clinical, haematological, serological and microbiological monitoring. Arquivos do Instituto Biológico 80: 273-280.

SEYFFERT $N$ et al. 2010. High seroprevalence of caseous lymphadenitis in Brazilian goat herds revealed by Corynebacterium pseudotuberculosis secreted proteins-based ELISA. Research in Veterinary Science 88: 50-55.

SILVA JB et al. 2014. A comparative study of production performance and animal health practices in organic and conventional dairy systems. Tropical Animal Health and Production 46: 1287-1295.

SOARES SC et al. 2012. PIPS: Pathogenicity island prediction software. PLoS ONE 7: e30848.

SOUZA MF et al. 2011. Linfadenite caseosa em ovinos deslanados abatidos em um frigorífico da Paraíba. Pesquisa Veterinária Brasileira 31: 224-230.

THRUSFIELD MV. 2004. Epidemiologia Veterinária. 2.ed. São Paulo: Roca. 556p.

VALLI VEO \& PARRY BW. 1993. Caseous Iymphadenitis. In: JUBB KVF et al. Pathology of Domestic Animals. 4.ed. San Diego: Academic Press. p.238-240.

WINDSOR PA. 2011. Control of caseous lymphadenitis. Veterinary Clinics of North America: Food Animal Practice 27: 193-202. 